\title{
REVIEW
}

\section{Biomedically relevant chemical constituents of Valeriana officinalis}

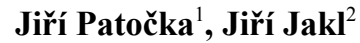 \\ ${ }^{1}$ Department of Radiology and Toxicology, Faculty of Health and Social Studies, University of South Bohemia \\ České Budějovice, Czech Republic \\ ${ }^{2}$ Department of Dendrology and Forest Tree Breeding, Faculty of Forestry and Wood Sciences, Czech University \\ of Life Sciences, Prague, Czech Republic
}

Received $24^{\text {th }}$ July 2009.

Revised $15^{\text {th }}$ October 2009.

Published online $1^{\text {st }}$ December 2009.

\begin{abstract}
Summary
Valerian is used to treat sleeping disorders, restlessness and anxiety, but it seems only to work when taken over long periods (several weeks). Some studies have demonstrated that valerian extracts interact with the GABA and benzodiazepine receptors. Valerian is also used traditionally to treat gastrointestinal pain and spastic colitis. There are no long term safety studies. Valerian contains over 150 chemical constituents and many of them are physiologically active, mainly pyridine alkaloids, some organic acids and terpenes, especially the so called valepotriates, esterified iridoid-monoterpenes. As valepotriates may be potential mutagens, valerian should only be used after consultation with a physician. Valerian medication is sometimes recommended as first line treatment when the benefit-risk relation requires it and is often indicated as transition medication during the discontinuation processes involving bromazepam, clonazepam and diazepam, among others.
\end{abstract}

Key words: Valeriana officinalis; valerian; chemical constituents; alkaloids; terpenes; valepotriates

\section{INTRODUCTION}

The herbal medicine valerian, the dried root of the plant Valeriana officinalis L., has been used as a medicinal herb since at least the time of ancient Greece and Rome. Its phytotherapeutical properties were described by Hippocrates as sedative and anti-anxiety. Galen prescribed it as a remedy for

Jiří Patočka, Department of Radiology and Toxicology, Faculty of Health and Social Studies, University of South Bohemia in České Budějovice, 37001 České Budějovice, Czech Republic prof.patocka@gmail.com

용 +420494661014 insomnia. Related species of the Valerianaceae family, were used in traditional Chinese and Indian Ayurvedic medicine (Jarema 2008).

Valerian extracts became popular in the United States and Europe in the mid-1800s and continued to be used by both physicians and the lay public until it was widely replaced by prescription sedative drugs. Other common uses included the treatment of headaches, anxiety, palpitations, irritable or spastic bowel, menstrual cramps, high blood pressure, epilepsy and childhood behavior problems and learning (Klich 1975). During World War I, valerian was used to prevent and treat shell shock in frontline troops, and it was used during World War II to help calm civilians subjected to air raids (Mowrey 1986). In 1998, valerian was the $10^{\text {th }}$ most popular herbal remedy sold in the United States (Fugh-Berman and Cott 1999). 
The mechanism of action of valerian in general, and in particular as a mild sedative, remains unknown. The aim of this article is to describe the biomedically active chemical constituents of valerian, and to review, its chemistry, biochemistry, pharmacology and toxicology.

\section{BOTANY}

The family Valerianaceae comprises 10 genera and about 300 species (Simpson 2006), or the Valeriana genus is of the family Caprifoliaceae and comprises about 200 species (Judd et al. 2002). The Valerianaceae are mostly distributed worldwide and consist of herbs, rarely shrubs, with opposite leaves, a sympetalous, spurred corolla, 1-4 stamens, and a tricarpellate, inferior ovary with 1 functional locule and a single, apical ovule, the fruit is an achene, with a pappuslike calyx in some members. The economic uses include some cultivated ornamentals (e.g. Centranthus) and minor edible, medicinal, or essential oil plants.

\section{ETHNOBOTANY}

Valeriana officinalis is native to Europe and Asia and has naturalized in eastern North America. This tall perennial prefers moist woodlands; it has been extensively cultivated in northern Europe. Most of the European supply is grown in Holland. It is cultivated in low lying, damp sandy humus with a lime fertilizer. It is harvested in the late fall and dried. $V$. officinalis is the species used in Europe. The genus contains over 250 species, with many more subspecies. $V$. fauriei is used in traditional Chinese and Japanese medicine (Huang 1999, Hikino et al. 1971, 1972a, b). $V$. capensis is used in African traditional medicine (Iwu 1993), V. edulis is used in Mexico and V. wallichii is used in India (Schulz et al. 1997).

\section{MEDICINAL USE}

The roots of $V$. officinalis known as valerian have a long history of use as a sedative medicine in Europe. Valerian is a mild sedative and sleep-promoting agent that is often used as a milder alternative or a possible substitute for stronger synthetic sedatives, such as the benzodiazepines, in the treatment of nervous states and anxiety-induced sleep disturbances (Miyasaka et al. 2006). Presently, valerian extracts are available as dietary supplements, which are primarily comprised of dried root or extracts from the root, formulated into tablets or soft gelatin capsules. Each dose contains between approximately $50 \mathrm{mg}$ and approximately 1 gram of dried root or extract. The use of these dietary supplements is extensive, with an estimated 210 million doses sold annually in the United States and 125 million doses sold annually in Europe (Grunwald 1995).

It has been recommended for epilepsy but that is not supported by research (Spinella 2001). The current indications for valerian are restlessness, insomnia, nervousness, and tension (Tariq and Pulisetty 2008). Large doses are known to cause withdrawal symptoms when stopped (Garges et al. 1998), as it, as well as most all sleep aids, may result in dependency. Those with liver disease are advised not to use valerian (Cohen and Del Torro 2008). While shown to be an effective remedy for the reduction of anxiety, it has also been reported to cause headaches and night terrors in some individuals. This is due to the fact that some people lack a digestive conversion property necessary to effectively break down valerian. In these individuals, valerian can cause agitation (Dennehy et al. 2005).

One study found that valerian tends to sedate the agitated person and stimulate the fatigued person, bringing about a balancing effect on the system (Müller and Klement 2006).

It is not fully understood which constituents of $V$. officinalis, and/or of the other heretofore unidentified members of the Valerianaceae family, are responsible for the sedative and/or anxiolytic action of valerian extracts. Nevertheless, the valepotriates (iridoids) as well as valerenic acid, a sesquiterpenoid compound, and the derivatives of valerenic acid are present in valerian extracts. Of these components, the valepotriates and valerenic acids are generally considered to contribute to the sedative action of valerian extracts, but have not been clearly and positively identified as such (Hendriks et al. 1981).

\section{CONSTITUENTS - CHEMISTRY AND PHARMACOLOGY}

Valerian contains over 150 chemical constituents and many of them are physiologically active (Jiang et al. 2007). There is substantial variation in the chemical constituents in plants from different sources and growing conditions, processing methods and storage conditions but the differences are small (Wagner et al. 1972). In order to guarantee the quality of the drug, 
producers have standardized production of the plant extracts (Gutierrez et al. 2004).

The known pharmacologically active compounds detected in valerian extract are alkaloids, terpenes, organic acids and its derivatives, valepotriates and flavones. It is generally accepted that the valepotriates are the compounds responsible for the sedative activity of the Valerianaceae.

\section{Alkaloids}

Alkaloids are present in amounts of $0.01-0.05 \%$ and there are also terpene alkaloids present (Duke 1985). The principal valerian alkaloids are actinidine, chatinine, valerianine, valerine, alpha-methyl pyrryl ketone and naphthyridin methyl ketone (Torssell and Wahlberg 1967, Franck et al. 1970, Janot et al. 1979). The structures of some valerian alkaloids are shown in Fig. 1.<smiles>[R]=COC</smiles>

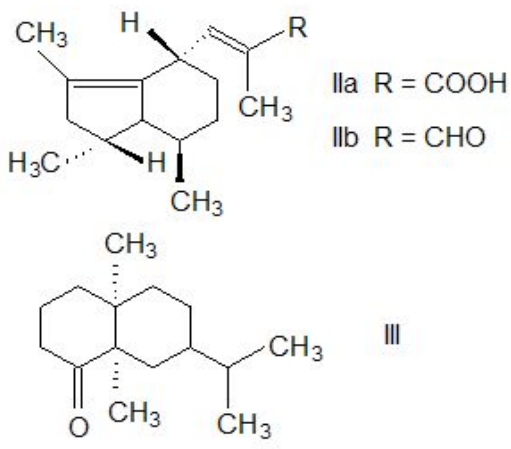

Fig. 1. The structures of principal compounds present in volatile essential oil of Valeriana officinalis. Valerian alkaloids actinidine (Ia) and valerianine (Ib), valerenic acid (IIa), its aldehyde valerenal (IIb) and terpene valeranone (III).

Actinidine (Ia) is a steam-volatile monoterpenoid pyridine alkaloid with a cyclopenta[c]pyridine skeleton found in the essential oil of valerian root (Johnson and Waller 1971) and Actinidia polygama (silver vine) (Sakan 1967). Actinidine is a cat attractant, with similar effects as nepetalactone, the active compound found in catnip (Nepeta cataria).
The alkaloid actinidine has been identified as an anal gland product of two species of dolichoderine ants in the genus Conomyrma (Wheeler et al. 1977) and is also a pheromone for a variety of insects and an important component of the defensive secretions of rove beetles of various staphylinid species (Bellas et al. 1974). Biosynthesis of actinidine results from lysine and quinolinic acid as precursors (Auda et al. 1967). Actinidine is a psychoactive alkaloid that interferes with the GABA-ergic metabolism; it is an agonist on benzodiazepine receptors and thus exhibits an allosteric modulation of the GABA-receptor-proteins.

Chatinine was isolated from valerian by Waliszewski (see Baby et al. 2005) but its biological properties have not been studied; similarly poor information exists about valerianine (Ib) and valerine although there are pyridine alkaloids close to actinidine (Janot et al. 1979). Alpha-methyl pyrryl ketone has been studied in Germany as a CNS active compound (Sándor et al. 1970). Synthetic naphthyridinones similar in structure to natural naphthyridyl methyl ketone were patented as potential drugs for the treatment of schizophrenia (Clark et al. 2005, Favor et al. 2006, Johnson et al. 2006). Since the pharmacological properties of valerian alkaloids have been studied separately only sporadically, it is difficult to say how these participate in the medical effects of V. officinalis.

\section{Organic acids and terpenes}

These compounds are present in the volatile essential oil which represents $0.2-2.8 \%$ of the dry weight of the root. The essential oils are not only present in the subrerranean parts of the plants but also in the aerial parts (Funke and Friedrich 1975). Terpenes are chemically characterized as monoterpenes and sesquiterpenes. Most considerable are valeric, isovaleric, valerenic, isovalerenic and acetoxyvalerenic acids, bornyl acetate, bornyl isovalerenate, 1-pinene, 1-comphene, 1-borneol, terpineol, valeranone and cryptofauronol. Some of the oil components were suggested to have sedative properties. Isovaleric acid and bornyl isovalerate are compounds responsible for the characteristic aroma of valerian.

Valeric acid, or n-pentanoic acid - straight-chain fatty acid - has a very unpleasant odor. It is interesting that the volatile esters of valeric acid tend to have pleasant odors and are used in perfumes and cosmetics. This is also true of isovaleric acid, 3-methylbutanoic acid. Both acids have non-significant pharmacological and toxicological properties and share the drug's odor only. Nevertheless, it was recently found that isovaleric acid 
reduces ATPase activity in the synaptic membranes of the cerebral cortex and it is probably involved in the pathophysiology of the neurological dysfunction of isovaleric acidemic patients (Ribeiro et al. 2007).

Valerenic acid (IIa) and its aldehyde valerenal (IIb) are pharmacologically active monoterpenes. It has been suggested that valerian acts via gamma-aminobutyric acid (GABA) mechanisms (Cavadas et al. 1995) and previous studies have shown binding of valerian extract to GABA receptors, but the functional effect of the binding has not been demonstrated. Data from the study of Yuan et al. (2004) suggest that the pharmacological effects of valerian extract and valerenic acid are mediated through modulation of $\mathrm{GABA}_{\mathrm{A}}$ receptor function. Thus, the pharmacological effects of valerian extract and valerenic acid are mediated through modulation of the $\mathrm{GABA}_{\mathrm{A}}$ receptor function. Thus, valerian may potentiate the sedative effects of anaesthetics and other medications that act on GABA receptors, and presurgical valerian use may cause a valerian-anaesthetic interaction. Valerenic acid was recently identified as a $\mathrm{GABA}_{\mathrm{A}}$ receptor modulator (Trauner et al. 2008) and is known to penetrate into the central nervous system transcellularly by passive diffusion (Neuhaus et al. 2008). Dietz et al. (2005) showed that valerenic acid is also a partial agonist of the $5 \mathrm{HT}$ receptor with the strong binding affinity to the 5-HT(5a) receptor, but only weak binding affinity to the 5-HT(2b) and the serotonin transporter. Valerenic acid, acetylvalerenolic acid and valerenal were active as inhibitors of NF- $\kappa \mathrm{B}$ at a concentration of $100 \mu \mathrm{g} / \mathrm{ml}$. Acetylvalerenolic acid reduced NF- $\kappa B$ activity to $4 \%$, whereas valerenic acid (3) reduced NF- $\kappa \mathrm{B}$ activity to $25 \%$ (Jacobo-Herrera et al. 2006).

Valeranone (III) was tested as a medical drug in hyperkinetic behaviour disorders (Gupta and Virmani 1968). Valeranone was pharmacologically investigated in animal experiments of its sedative, tranquilizing and antihypertensive properties but the activity of valeranone was lower than those of the standard substances used (Rücker et al. 1978). The structures of principal compounds present in volatile essential oil are shown in Fig. 1. Other volatile terpenes are bornyl isovalerate, bornyl acetate, bornyl formate, eugenyl isovalerate, isoeugenyl isovalerate, and many terpenic alcohols, aldehydes, ketones and esters (Hikino et al. 1965).

\section{Valepotriates}

Valepotriates are esterified iridoid-monoterpenes. Their name is derived from the valeriana-epoxy-triester, because these are triesters of polyhydroxycyclopenta-(c)-pyrans with carboxylic acids: acetic, valeric, isovaleric,

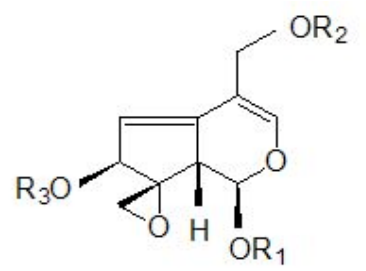

$$
\begin{aligned}
& \text { IVa } R_{1}=I v, R_{2}=A c, R_{3}=I V \\
& \text { IVb } R_{1}=I v, R_{2}=I V, R_{3}=A c \\
& \text { IVC } R_{1}=I V, R_{2}=A c, R_{3}=A C \\
& I V d R_{1}=I v, R_{2}=A c, R_{3}=M V
\end{aligned}
$$

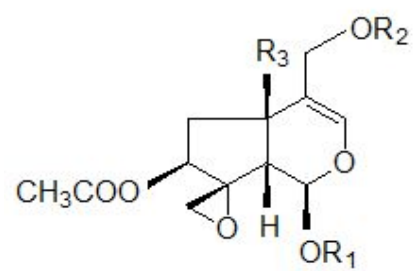

$$
\begin{gathered}
\text { Va } R_{1}=I v, R_{2}=I v, R_{3}=H \\
V b \quad R_{1}=I v, R_{2}=I V-I v, R_{3}=O H
\end{gathered}
$$<smiles>[R]Oc1cocc2c(OC)ccc1-2</smiles>

Vla $\mathrm{R}=\mathrm{Ac} \quad \mathrm{Vlb} \mathrm{R}=\mathrm{IV}$

Fig. 2. The structures of principal compounds of Valeriana officinalis, valepotriates and their degradation products, baldrinals. Diene valepotriates: valtrate (IVa), isovaltrate (IVb), 7-desisovaleroyl-7-acetyl-valtrate (IVc) and homovaltrate (IVd), and monoene valepotriates: didrovaltrate $(\mathrm{Va})$ and isovaleoxyhydroxydidrovaltrate $(\mathrm{Vb})$. Degradation products of valtrates are: baldrinal (VIa) and homobaldrinal (VIb).

Abbreviations: Ac $=$ acetyl, Iv $=$ isovaleryl, Iv-Iv = isovaleryloxyisovaleryl, $\mathrm{MV}=\beta$-methylvaleryl.

$\alpha$-isovaleroxy-isovaleric, $\beta$-methylvaleric, $\beta$-acetoxy-isovaleric, $\beta$-hydroxyisovaleric and $\beta$-acetoxy- $\beta$-methylvaleric acid (Thies 1969). It is a major component consisting of $50-80 \%$ active compounds. Valepotriates are divided into two clases: monoene and the diene derivatives. The structures of some valepotriates are shown in Fig. 2. The principal 
diene valepotriates are valtrate (IVa), isovaltrate $(\mathrm{IVb}), 7-d e s i s o v a l e r o y l-7-a c e t y l v a l t r a t e(\mathrm{IVc})$ and 7-homovaltrate (IVd), and the main monoene derivatives are didrovaltrate (Va) and isovaleroxyhydroxydidrovaltrate $(\mathrm{Vb})$. The amount of valepotriates varies widely between species. The underground parts contain normally higher amount of valepotriates than the other parts of the plant (Violon et al. 1984).

In an in vivo and in vitro investigation of valepotriates and valeranone on guinea-pig ileum smooth muscle preparations it was found that dihydrovalerate and valeranone were able to relax stimulated smooth muscle preparations with a potency comparable to that of papaverine. Moreover, it was shown that these valeriana compounds induced smooth muscle relaxation via a musculotropic action, which is also known to be the case for papaverine (Hazelhoff 1984).

The valepotriates isovaltrate and valtrate, as well as valeranone caused a suppression of rhythmic contractions in a closed part of the guinea-pig ileum in vivo. The same compounds relaxed potassium stimulated contractures and inhibited $\mathrm{BaCl}_{2}$ contractions in guinea-pig ileum preparations in vitro. Valeranone and didrovaltrate were about equipotent to papaverine in inhibiting $\mathrm{BaCl}_{2}$ contractions. Guinea-pig stomach fundic strips stimulated by carbachol were also relaxed by these substances. Potassium stimulated smooth muscle cells were also relaxed by the valeriana compounds (Hazelhoff et al. 1982).

Valepotriates are very unstable compounds and are sensitive to temperature, acids and alkali. Their degradation products are known as baldrinals. Major decomposition products of the valepotriates are the baldrinal (VIa) and homobaldrinal (VIb). Baldrinals reduced the spontaneous motor activity of light-dark synchronized mice (Veith et al. 1986).

\section{MECHANISM OF ACTION}

Because of valerian's historical use as a sedative, anti-convulsant, migraine treatment and pain reliever, most basic science research has been directed at the interaction of valerian constituents with the GABA neurotransmitter receptor system (Trauner et al. 2008). The mechanism of action of valerian in general, as a mild sedative in particular, remains unknown (Wheatley 2005). Valerian extracts and some of its constituents, mainly valerenic acid, appear to have some affinity for the $\mathrm{GABA}_{\mathrm{A}}$ receptor, but the exact mechanism of action is not yet known. Benke et al. (2009) have described a specific binding site on $\mathrm{GABA}_{\mathrm{A}}$ receptors with $\mathrm{nM}$ affinity for valerenic acid and valerenol, common constituents of valerian. Both agents enhanced the response to GABA at multiple types of recombinant $\mathrm{GABA}_{\mathrm{A}}$ receptors. A point mutation in the beta 2 or beta 3 subunit of recombinant receptors strongly reduced the drug response. In vivo, valerenic acid and valerenol have anxiolytic activity with high potencies in the elevated plus maze and the light/dark choice test in wild type mice. In beta3 point-mutated mice the anxiolytic activity of valerenic acid was absent. Thus, neurons expressing beta3 containing $\mathrm{GABA}_{\mathrm{A}}$ receptors are a major cellular substrate for the anxiolytic action of valerian extracts (Benke et al. 2009). Valerenic acid is a $\mathrm{GABA}_{\mathrm{A}}$ receptor modulator (Trauner et al. 2008). Substances such as valerenic acid and its derivatives acetoxyvalerenic acid and hydroxyvalerenic acid have to cross the blood-brain barrier and interact with this receptor in the brain (Neuhaus et al. 2008). Transport of these terpenic acids was compared with the permeability of the $\mathrm{GABA}_{\mathrm{A}}$ modulator diazepam, which is known to penetrate into the central nervous system transcellularly by passive diffusion. It was hypothesized that the investigated terpenes from $V$. officinalis can probably only pass through the blood-brain barrier by a still unknown transport system and not transcellularly by passive diffusion (Neuhaus et al. 2008).

\section{ANIMAL BEHAVIOUR TESTS}

Hazelhoff (1984), in his dissertation, shows that the valerian preparations and compounds contained in $V$. officinalis extract cause a significant reduction in thelocomotor activity of mice, whereas of the valepotriates only didrovaltrate was found to be active in this test model (Hazelhoff 1984).

The effect of a mixture of valepotriates on the elevated plus-maze performance of diazepam withdrawn rats was evaluated by Andreatini and Leite (1994).

The rats were chronically (28 days) treated with diazepam (doses increased up to $5.0 \mathrm{mg} / \mathrm{kg}$ ) and then treated with a control solution for 3 days to induce a withdrawal syndrome. Chronically vehicle-treated rats were used as control. The abstinent animals treated with the vehicle showed a significant decrease in the percentage of time spent in the open arms when compared with the control animals. Diazepam and valerian $12.0 \mathrm{mg} / \mathrm{kg}$ reversed this anxiogenic effect. Valerian $6.0 \mathrm{mg} / \mathrm{kg}$ did not show any difference in relation to the other group. 


\section{TOXICOLOGY}

Numerous studies have indicated that aqueous and alcoholic extracts of $V$. officinalis are a little toxic and have high $\mathrm{LD}_{50}$ values. For example valeranone has $\mathrm{LD}_{50}$ for mice at i.p. administration $580 \mathrm{mg} / \mathrm{kg}$ (Holzl 1997). A unique case of overdose where the patient had ingested almost $25 \mathrm{~g}$ of powdered $V$. officinalis root in capsule form, demonstrated only mild symptoms (Willey et al. 1995) which included fatigue, abdominal cramps and tremor; all of the symptoms disappeared within 24 hours.

The clinical evidence indicates that valerian is a relatively safe substitute for the benzodiazepines as a mild tranquilizer. It was traditionally contraindicated in pregnancy, but until recently there were no studies to warrant this warning. An Australian study (Yao et al. 2007) on female rats which were orally dosed with a valerian extract daily on either gestation days $1-8$ or $8-15$ indicated that valerian had no adverse effects on fertility or foetal development.

Literature reports have suggested that valerian induces genotoxicity in vitro (ECV304 cells) by a reactive oxygen species-mediated mechanism (Hui-lian et al. 2003); however, there are no reports on its genotoxicity and/or the epigenetic mechanism in vivo (Al-Majed et al. 2006).

Genotoxicity has been reported for both baldrinal and homobaldrinal, the decomposition products of valtrate and isovaltrate. These compounds showed direct mutagenic effects in vitro in the AMES assay and the SOS-chromo-test (Hude et al. 1986). Studies on the effects of baldrinals on haemopoietic cells in vitro (Braun et al. 1986), indicating decreased liver function.

\section{CONCLUSIONS}

Valerian (Valeriana officinalis) is widely known for its use as a sedative and an anti-anxiety drug in folk medicine. The root of valerian is used most commonly for its sedative and hypnotic properties in patients with insomnia, and less commonly as an anxiolytic. The chemical composition of valerian includes sesquiterpenes of the volatile oil (including valeric acid), iridoids (valepotriates), alkaloids, and free amino acids. Although the sesquiterpene components of the volatile oil are believed to be responsible for most of valerian's biologic effects, it is likely that all of the active constituents of valerian act in a synergistic manner to produce a clinical response. Valerian is a safe herbal choice for the treatment of mild insomnia and has good tolerability.

\section{REFERENCES}

Al-Majed AA, Al-Yahya AA, Al-Bekairi AM, Al-Shabanah OA, Qureshi S: Studies on the cytological and biochemical effects of valerian in somatic and germ cells of Swiss albino mice. Food Chem Toxicol 44:1830-1837, 2006.

Andreatini R, Leite JR: Effect of valepotriates on the behavior of rats in the elevated plus-maze during diazepam withdrawal. Eur J Pharmacol 260:233-235, 1994.

Auda H, Waller GR, Eisenbraun EJ: Biosynthesis of methylcyclopentane monoterpenoids. 3. Actinidine. J Biol Chem 242:4157-4160, 1967.

Baby R, Cabezas M, Castro E, Filip R, Walsöe de Reca NE: Quality control of medicinal plants with an electronic nose. Sens Actuators B Chem 106:24-28, 2005.

Bellas TE, Brown WV, Moore BP: The alkaloid actinidine and plausible precursors in defensive secretions of rove beetles. J Insect Physiol 20:277-280, 1974.

Benke D, Barberis A, Kopp S, Altmann KH, Schubiger M, Vogt KE, Rudolph U, Möhler H: GABA(A) receptors as in vivo substrate for the anxiolytic action of valerenic acid, a major constituent of valerian root extracts. Neuropharmacology 56:174-181, 2009.

Braun R, Dieckmann H, Machut M, Echarti C, Maurer HR: Studies on the effects of baldrinal on hemopoietic cells in vivo, on the metabolic activity of the liver in vivo, and on the content in proprietry drugs (in German). Planta Med 52:446-450, 1986.

Cavadas C, Araújo I, Cotrim MD, Amaral T, Cunha AP, Macedo T, Ribeiro CF: In vitro study on the interaction of Valeriana officinalis L. extracts and their amino acids on $\mathrm{GABA}_{\mathrm{A}}$ receptor in rat brain. Arzneimittelforschung 45:753-755, 1995.

Clark J, Davis J, Favor DA, Fay L, Franklyn L, Heneger K, Johnson D, Zhijian Z: $[1,8]$ Naphthyridin-2-ones and related compounds for the treatment of schizophrenia. US Patent WO2005019215, March 3, 2005.

Cohen DL, Del Torro Y: A case of valerian-associated hepatotoxicity. J Clin Gastroenterol 42:961-962, 2008.

Dennehy CE, Tsourounis C, Horn AJ: Dietary supplement-related adverse events reported to the California Poison Control System. Am J Health Syst Pharm 62:1476-1482, 2005.

Dietz BM, Mahady GB, Pauli GF, Farnsworth NR: Valerian extract and valerenic acid are partial agonists of the 5-HT5a receptor in vitro. Brain Res Mol Brain Res 138:191-197, 2005. 
Duke JA: CRC Handbook of Medicinal Herbs. CRC Press, Boca Raton 1985.

Favor DA, Johnson DS, Repine JT, White AD: Isoquinoline $[1,8]$ naphthyridin-2-ones and related compounds for treatment os schizophrenia. US Patent WO2006090272, August 31, 2006.

Franck B, Petersen U, Huper F: Valerianine, a tertiary monoterpene alkaloid from valerian. Angew Chem Int Ed Engl 9:891, 1970.

Fugh-Berman A, Cott JM: Dietary supplements and natural products as psychotherapeutic agents. Psychosom Med 61:712-728, 1999.

Funke ED, Friedrich H: Valepotriates in the aerial parts of some more valerianaceae species (in German). Planta Med 28:215-224, 1975.

Garges HP, Varia I, Doraiswamy PM: Cardiac complications and delirium associated with valerian root withdrawal. JAMA 280:1566-1567, 1998.

Grunwald J: The European Phytomedicines Market-Figures, Trends Analyses. Herbal Gram, Austin 1995.

Gupta PD, Virmani V: Clinical trial of jatamansone (syn: valeranone) in hyperkinetic behaviour disorders. Neurol India 16:168-173, 1968.

Gutierrez S, Ang-Lee MK, Walker DJ, Zacny JP: Assessing subjective and psychomotor effects of the herbal medication valerian in healthy volunteers. Pharmacol Biochem Behav 78: 57-64, 2004.

Hazelhoff B: Phytochemical and pharmacological aspects of valerian compounds. With special reference to valepotriates. Dissertation Thesis, University of Groningen, Groningen 1984.

Hazelhoff B, Malingré TM, Meijer DK: Antispasmodic effects of valeriana compounds: an in-vivo and in-vitro study on the guinea-pig ileum. Arch Int Pharmacodyn Ther 257:274-287, 1982.

Hendriks H, Geertsma HJ, Th. M. Malingré TM: The occurence of valeranone and crypto-fauronol in the essential oil of Valeriana offcinalis L. s. 1. collected in the northern part of The Netherlands. Pharm World Sci 3:1316-1320, 1981.

Hikino H, Hikino Y, Kato H, Takeshita Y, Takemoto T: Constituents of wild Japanese valerian root. 1. Yakugaku Zasshi 91:766-769, 1971.

Hikino H, Ono M, Takemoto T: Constituents of wild Japanese valerian root. 2. Yakugaku Zasshi 92:479-481, 1972a.

Hikino H, Hikino Y, Nakamara R, Ono M, Takemoto T: Constituents of wild Japanese valerian root. 3. Yakugaku Zasshi 92:498-502, 1972b.

Hikino H, Takeshita Y, Hikino Y, Takemoto T: Structure of fauronyl acetate and cryptofauronol. Chem Pharm Bull (Tokyo) 13:631-632, 1965.
Holzl J: The pharmacology and therapeutics of valeriana. In Houghton PJ (ed.): Valerian. The Genus Valeriana, Harwood Acad Publ., Amsterdam 1997, pp. 55-74.

Huang KC: The Pharmacology of Chinese Herbs. CRC Press, Boca Raton 1999.

Hude von der W, Scheutwinkel-Reich M, Braun R: Bacterial mutagenicity of the tranquilizing constituents of Valerianaceae roots. Mutat Res 169:23-27, 1986.

Hui-lian W, Dong-fang Z, Zhao-feng L, Yang L, Qian-rong L, Yu-zhen W: In vitro study on the genotoxicity of dichloromethane extracts of valerian (DEV) in human endothelial ECV304 cells and the effect of vitamins $\mathrm{E}$ and $\mathrm{C}$ in attenuating the DEV-induced DNA damages. Toxicol Appl Pharmacol 188:36-41, 2003.

Iwu MM: Handbook of African Medicinal Plants. CRC Press, Boca Raton 1993.

Jacobo-Herrera NJ, Vartiainen N, Bremner P, Gibbons $\mathrm{S}$, Koistinaho J, Heinrich M: NF- $\mathrm{BB}$ modulators from Valeriana officinalis. Phytother Res 20:917-919, 2006.

Janot MM, Guilhem J, Contz O, Venera G, Cionga E: Contribution to the study of valerian alcaloids (Valeriana officinalis L.): actinidine and naphthyridylmethylketone, a new alkaloid. Ann Pharm Fr 37:413-420, 1979.

Jarema M: Herbal drug treatment. Neuro Endocrinol Lett 29 (Suppl. 1):93-104, 2008.

Jiang X, Zhang JC, Liu YW, Fang Y: Studies on chemical constituents of Valeriana officinalis (in Chinese). Zhong Yao Cai 30:1391-1393, 2007.

Johnson DS, Singer JM, White AD: $[1,8]$ Naphthyridin-2-ones and related compounds with keto or hydroxyl linkers for the treatment of schizophrenia. US Patent WO2006090273, August 31, 2006.

Johnson RD, Waller GR: Isolation of actinidine from Valeriana officinalis. Phytochemistry 10:3334-3335, 1971.

Judd WS, Campbell CS, Kellogg EA, Stevens PF, Donoghue MJ: Plant Systematics, a Phylogenetic Approach. Sinauer Associates, Sunderland 2002.

Klich R: Behavior disorders in childhood and their therapy. Med Welt 26:1251-1254, 1975.

Miyasaka LS, Atallah AN, Soares BG: Valerian for anxiety disorders. Cochrane Database Syst Rev 18:CD004515, 2006.

Mowrey DB: The Scientific Validation of Herbal Medicine. Keats Pub., New Cannan 1986, p. 316.

Müller SF, Klement S: A combination of valerian and lemon balm is effective in the treatment of restlessness and dyssomnia in children. Phytomedicine 13:383-387, 2006 
Neuhaus W, Trauner G, Gruber D, Oelzant S, Klepal W, Kopp B, Noe CR: Transport of a GABA receptor modulator and its derivatives from Valeriana officinalis L. s. 1. across an in vitro cell culture model of the blood-brain barrier. Planta Med 74:1338-1344, 2008.

Ribeiro CA, Balestro F, Grando V, Wajner M: Isovaleric acid reduces $\mathrm{Na}^{+}, \mathrm{K}^{+}$-ATPase activity in synaptic membranes from cerebral cortex of young rats. Cell Mol Neurobiol 27:529-540, 2007.

Rücker G, Tautges J, Sieck A, Wenzl H, Graf E: Isolation and pharmacodynamic activity of the sesquiterpene valeranone from Nardostachys jatamansi DC (in German). Arzneimittelforschung 28:7-13, 1978.

Sakan T: Matatabi (Actinidia polygama Miq.)-isolation and structure of its biologically active components (in Japanese). Tanpakushitsu Kakusan Koso 12:2-9, 1967.

Sándor P, Kovách AG, Horváth KB, Szentpétery GB, Clauder O: Pharmacological studies on the effect of synthetic alpha-methyl-pyrryl-ketone on the central nervous system and blood circulation (in German). Arzneimittelforschung. 20:29-32, 1970.

Simpson MG: Plant Systematics. Elsevier, Amsterdam 2006.

Schulz V, Hansel R, Tyler VE: Rational Phytotherapy: A Physicians' Guide to Herbal Medicine. Springer, Berlin 1997, p. 306.

Spinella M: Herbal medicines and epilepsy: The potential for benefit and adverse effects. Epilepsy Behav 2:524-532, 2001.

Tariq SH, Pulisetty S: Pharmacotherapy for insomnia. Clin Geriatr Med 24:93-105, 2008.

Thies PW: On the chromomgenic behavior of valepotriate. 5. Report on the active substances of Valerian (in German). Arzneimittelforschung 19:319-322, 1969.
Torssell K, Wahlberg K: Isolation, structure and synthesis of alkaloids from Valeriana officinalis L. Acta Chem Scand 21:53-62, 1967.

Trauner G, Khom S, Baburin I, Benedek B, Hering S, Kopp B: Modulation of $\mathrm{GABA}_{\mathrm{A}}$ receptors by valerian extracts is related to the content of valerenic acid. Planta Med 74:19-24, 2008.

Veith J, Schneider G, Lemmer B, Willems M: The influence of some degradation products of valepotriates on the motor activity of light-dark synchronized mice (in German). Planta Med 52:179-183, 1986.

Violon C, Dekegel D, Vercruysse A: Relation between valepotriate content and differentiation level in various tissues from Valerianeae. J Nat Prod 47:934-940, 1984.

Wagner H, Schaette R, Horhammer L, Holzl J: Dependence of the valepotriate and essential oil content in Valeriana officinalis L. on various exogenous and endogenous factors. Arzneimittelforschung 22:1204-1209, 1972.

Wheatley D: Medicinal plants for insomnia: a review of their pharmacology, efficacy and tolerability. J Psychopharmacol 19:414-421, 2005.

Wheeler JW, Olagbemiro T, Nash A, Blum MS: Actinidine from defensive secretions of dolichoderine ants. J Chem Ecol 3:241-244, 1977.

Willey LB, Mady SP, Cobaugh DJ, Wax PM: Valerian overdose: a case report. Vet Hum Toxicol 37:364-365, 1995.

Yao M, Ritchie HE, Brown-Woodman PD: A developmental toxicity-screening test of valerian. J Ethnopharmacol 113:204-209, 2007.

Yuan CS, Mehendale S, Xiao Y, Aung HH, Xie JT, Ang-Lee MK: The gamma-aminobutyric acidergic effects of valerian and valerenic acid on rat brainstem neuronal activity. Anesth Analg 98:353-358, 2004. 